\title{
PENGEMBANGAN LEMBAR KERJA SISWA BERBASIS KEARIFAN LOKAL
}

\author{
Azizahwati ${ }^{1,2)}$, Ruhizan Mohd Yasin ${ }^{2)}$ \\ ${ }^{1)}$ Program Studi Pendidikan Fisika FKIP, Universitas Riau, \\ ${ }^{2)}$ Fakulti Pendidikan, University Kebangsaan Malaysia \\ e-mail: aziza_ur@yahoo.com
}

\begin{abstract}
Abstrak
Penelitian ini bertujuan untuk mengembangkan lembar kerja siswa berbasis kearifan lokal untuk siswa SMP kelas VIII yang valid. Penelitian ini menggunakan metode Research and Development (R\&D) dengan mengacu pada model 4 D. Instrumen yang digunakan adalah lembar validasi LKS dan angket respon pengguna dari guru dan siswa. Penelitian yang telah dilaksanakan memberikan kesimpulan: kualitas LKS yang dikembangkan mendapatkan nilai dengan kategori tinggi serta respon pengguna dari guru yang sangat tinggi dan dari siswa yang berkategori tinggi sehingga layak digunakan.
\end{abstract}

Kata kunci: kearifan lokal, Lembar Kerja Siswa, research and development

\begin{abstract}
This study aims to develop an indigenous knwledge-based student worksheets for valid Grade VII junior high school students. This research uses Research and Development ( $R \& D)$ method with reference to model 4 D. The instruments used are LKS validation sheets and user response questionnaires from teachers and students. The research that has been carried out concludes: the quality of the developed LKS scores with high category as well as the user response from very high teachers and from the high categorized students so it is good to use.
\end{abstract}

Keywords: indigenous knowledge, the worksheets, research and development

\section{Pendahuluan}

Lembar Kerja Siswa (LKS) merupakan salah satu sumber belajar yang umumnya digunakan guru. LKS harus dapat memandu aktivitas belajar siswa secara terarah dan sistematis dalam mencapai tujuan pembelaja ran (Trianto, 2013). Lembar Kerja siswa (LKS) dapat berupa panduan untuk latihan pengem bangan aspek kognitif maupun panduan untuk pengembangan semua aspek pembelajaran dalam bentuk panduan eksperimen atau demonstrasi. Menurut Andi Prastowo (2012) LKS memiliki 4 fungsi sebagai berikut: 1. Sebagai bahan ajar yang bisa meminimalkan peran pendidik, namun lebih mengaktifkan peserta didik. 2. Sebagai bahan ajar yang mempermudah peserta didik untuk memahami materi yang diberikan. 3 . Sebagai bahan ajar yang ringkas dan kaya tugas untuk berlatih. 4. Memudahkan pelakasanaan pengajaran kepada peserta didik. Tujuan pembuatan LKS (Belawati et al., 2012) adalah sebagai berikut: 1) Menyajikan bahan ajar yang memudahkan peserta didik untuk berinteraksi dengan materi yang diberikan. 2) Menyajikan meningkatkan tugas-tugas penguasaan yang peserta dapat didik terhadap 
materi yang diberikan. 3) Melatih kemandirian belajar peserta didik. 4) Memudahkan pendidik dalam tugas kepada peserta didik.

LKS yang dikombinasikan dengan kearifan lokal dapat digunakan guru sebagai sarana untuk melatihkan keterampilan siswa melakukan eksperimen. Lembar kerja siswa berbasis kearifan lokal akan sangat membantu dalam proses pembelajaran maupun proses kegiatan praktikum dilabor dalam menemukan dan memecahkan masalah sehingga menjadi temuan konsep baru dalam sains. Zuhdan K. Prasetyo (2013) menilai bahwa justru nilainilai yang dianut oleh masyarakat lokal yang penuh dengan nilai-nilai kearifan lokal diabaikan dalam berbagai pembelajaran, termasuk pembelajaran sains di sekolah. Padahal jika kearifan lokal dimasukkan ke dalam pembelajaran sains dapat meningkatkan kualitas pembelajaran tersebut sehingga pembelajaran menjadi bermakna bagi siswa. Menurut Hairida (2010) buku-buku yang digunakan dalam pembelajaran telah memenuhi sejumlah kriteria kelayakan yaitu kelayakan isi, penyajian, bahasa, dan grafik, akan tetapi bahan-bahan ajar termasuk LKS tersebut masih belum memadai sehingga pembelajran menjadi kurang bermakna. Disini terlihat perlunya pengembangan LKS yang dapat mengintegrasikan nilai-nilai budaya, dimana bahan ajar tersebut dapat dikonsumsi oleh siswa dimanapun mereka berada dan memiliki daya tarik kuat bagi siswa sehingga perlu digunakan nuansa kearifan lokal.

Menurut Gondwe dan Nancy (2014) kearifan lokal meliputi; nilai-nilai, normanorma, kepercayaan dan praktek-praktek yang dibagi, dibuat dan diwariskan dari generasi ke generasi yang disertai dengan teknologi lokal. Pemanfaatan budaya yang merupakan unsur kearifan lokal dapat menumbuhkan kesadaran diri dalam menjaga kelestarian alam (Clayton, 2009). Masyarakat telah mengembangkan pengetahuan yang telah diwariskan sebagai cara-cara atau teknologi asli daerah guna mendayagunakan sumber daya alam bagi kelangsungan hidup. Pengungkapan gagasan masyarakat yang bersifat lokal kedaerahan, dapat menguatkan hakekat belajar bermakna, dan mendorong setiap siswa di sekolah untuk bersifat bijaksana, penuh kearifan sehingga dapat memecahkan permasalahan dalam kehidupan sehari-hari. Materi ajar yang sekedar berisi konsep, dikhawatirkan menghasilkan generasi yang mengabaikan kearifan lokal sebagai pilar jati diri bangsa. Budaya yang merupakan unsur kearifan lokal yang berkembang dimasyarakat yang secara jelas telah teruji mampu menjaga keseimbangan lingkungan, sudah semestinya dijadikan bahan dalam pengembangan materi ajar sains.

Proses pembelajaran sains yang tepat memerlukan perencanaan yang tepat pula, perancangan LKS merupakan salah satu perencanaan yang harus disiapkan oleh guru untuk mencapai tujuan pembelajaran. LKS merupakan media, petunjuk, dan pedoman yang akan digunakan dalam proses pembelajaran (Suhadi dalam Rusmiati, 2007). Adapun tujuan dari penelitian ini adalah untuk menghasilkan LKS berbasis kearifan lokal kelas VIII yang valid.

\section{Bahan dan Metode}

Bentuk penelitian ini menggunakan development research yang dkembangkan oleh Thiagarajan, Semmel, dan Semmel (Nur, 2011). Kegiatan penelitian meliputi empat tahap, yaitu pendefinisian (define), peran cangan (design), pengembangan (develop), dan desiminasi terbatas ataupun luas.

Kegiatan penelitian diawali dengan tahap define yaitu dengan melaukan analisis kebutuhan yang meliputi: studi lapangan, menganalisis Kompetensi Dasar IPA (sanis) SMP, mereviu literatur tentang pengembangan lembar kerja siswa SMP kelas VIII. Tahap perancangan (design) melakukan perancangan LKS sesuai format sehingga dihasilkan draft awal (prototipe). Tahap pengembangan (develop), pada tahap ini dilakukan validasi dan revisi oleh pakar selanjutnya dilakukan uji coba kecil (praktikalitas) sebelum di diseminate (uji coba luas). Pada uji coba kecil ini diperoleh respon dari pengguna dalam hal ini guru dan siswa sebagai penambahbaikan LKS yang di kembangkan. Draf prototipe perangkat pembelajaran Fisika berbasis kearifan lokal divalidasi oleh 5 (lima) orang pakar pendidi kan sains fisika. Kegiatan validasi dilakukan dalam bentuk tertulis dan diskusi sampai tercapai suatu kondisi yang mana para validator berpendapat bahwa LKS yang dikembangkan sudah valid. LKS berbasis kearifan lokal yang telah direvisi dan valid 
menurut pakar, diuji coba (uji coba kecil) ke pengguna dalam hal ini guru dan siwa SMP untuk dimintai responnya terhadap LKS yang sudah dibuat. Masukan dari pengguna digunakan sebagai penambahbaikan perangkat sebelum di disseminate.

1. Instrument Pengumpulan Data

Instrumen yang dipakai dalam penelitian ini adalah: a) Lembar validasi perangkat pembelajara untuk pakar b) Angket respon guru dan siswa terhadap pembelajaran berbasis kearifan lokal.

2. Teknik Pengumpulan data

Teknik pengumpulan data dalam penelitian ini adalah 1). Angket yang digunakan untuk memperoleh data tentang tingkat validitas LKS yang dikembangkan bila digunakan dalam pembelajaran sains. Angket tersebut diberikan kepada validator. 2). Angket respon guru dan siswa (sebagai pengguna) terhadap LKS yang dikembangkan.

3. Teknik Analisis Data

Teknik analisis data yang digunakan dalam penelitian ini adalah analisis deskriptif, yakni dengan cara menghitung rata-rata skor validitas dari setiap indikator validitas LKS dan ratarata skor respon pengguna. Kevalidan ditentukan skor yang diberikan oleh ahli sebagai hasil validasi. Kelayakan LKS yang dikembangkan diperoleh dari skor Respon penngguna (pada uji coba skla kecil).

Tabel 1. Kategori validitas format LKS

\begin{tabular}{lc}
\hline \multicolumn{1}{c}{ Persentase } & Kategori \\
\hline $78 \% \leq \bar{x}<100 \%$ & Tinggi \\
$56 \% \leq \bar{x}<78 \%$ & Sedang \\
$33 \% \leq \bar{x}<56 \%$ & Rendah \\
\hline
\end{tabular}

Analisis data hasil validasi adalah sebagai berikut :

a. Menentukan validitas format LKS dengan berdasarkan ketentuan kategori validitas format LKS menurut Tabel 1.

b. Menghitung validitas isi LKS dengan langkah-langkah sebagai berikut
1) Menentukan skor untuk jawaban angket menggunakan skala Likert seperti pada Tabel 2 .

2) Mencari rata-rata tiap indikator angket

3) Mencari rata-rata keseluruhan angket.

4) Menentukan kategori rata-rata validasi.

Tabel 2. Skor penilaian angket

\begin{tabular}{clc}
\hline No & \multicolumn{1}{c}{ Kategori } & Skor \\
\hline 1 & Sangat Tinggi & 4 \\
2 & Tinggi & 3 \\
3 & Rendah & 2 \\
4 & Sangat Rendah & 1 \\
\hline
\end{tabular}

Sumber: (Sugiyono, 2015)

Tabel 3. Kategori validitas isi LKS

\begin{tabular}{ccl}
\hline No. & $\begin{array}{c}\text { Interval Nilai } \\
\text { Respon }(\%)\end{array}$ & \multicolumn{1}{c}{ Kategori } \\
\hline 1 & $3,25 \leq \mathrm{V}<4$ & Sangat Tinggi \\
2 & $2,50 \leq \mathrm{V}<3,25$ & Tinggi \\
3 & $1,75 \leq \mathrm{V}<2,50$ & Rendah \\
4 & $1,00 \leq \mathrm{V}<1,75$ & Sangat Rendah \\
\hline
\end{tabular}

Kriteria penarikan kesimpulan terhadap LKS yang dikembangkan ditetapkan sebagai berikut:

a. Masing-masing komponen penilaian format LKS dinyatakan valid apabila validitasnya tinggi sesuai Tabel 1.

b. Masing-masing komponen penilaian isi LKS dinyatakan valid apabila setiap pernyataan pada indikator memperoleh skor 3 dan 4, validitasnya tinggi atau sangat tinggi sesuai dengan Tabel 3 dan 4 .

Tabel 4. Kriteria respon pengguna LKS Fisika SMP berbasis kearifan lokal

\begin{tabular}{cll}
\hline No. & Interval Respon & Kategori Respon \\
\hline 1 & $3,25 \leq \mathrm{R}<4$ & Sangat Tinggi \\
2 & $2,50 \leq \mathrm{R}<$ Tinggi \\
& $3,25 \leq \mathrm{R}<$ Rendah \\
3 & $1,75 \leq \mathrm{R}<$ Sangat Rendah \\
& $2,50 \leq$ \\
4 & $1,00 \leq 0$ \\
& 1,75
\end{tabular}

Sumber: (Sugiyono,2015) 
Praktikalitas (respon pengguna) LKS berbasis kearifan lokal, dilihat dari respon guru dan peserta didik terhadap LKS. LKS dinyatakan layak digunakan jika respon pengguna berada pada kategori tinggi atau sangat tinggi.

\section{Hasil dan Pembahasan}

Penegembangan LKS berbasis kearifan lokal yang telah dilakukan menunjukkan hasil seperti pada Tabel 5 dan Tabel 6.

Tabel 5. Hasil validasi format LKS berbasis kearifan lokal

\begin{tabular}{cll}
\hline No & \multicolumn{1}{c}{ Indikator } & $\begin{array}{c}\text { Persentase } \\
(\%) / \text { Kategori }\end{array}$ \\
\hline 1 & Judul & 100/Tinggi \\
2 & Mencantumkan & $100 /$ Tinggi \\
& tujuan & \\
3 & Alat/bahan (jika ada) & $100 /$ Tinggi \\
4 & Langkah kerja & 100/Tinggi \\
5 & Kolom & $100 /$ Tinggi \\
& pengamatan/grafik & \\
6 & Pertanyaan & $100 /$ Tinggi \\
\hline & Rata-rata/Kategori & $100 /$ Tinggi \\
\hline
\end{tabular}

Hasil validasi format LKS pada Tabel 5 memperlihatkan validitas $100 \%$ yang menggambarkan kelengkapan komponen LKS. Tabel 6 menunjukkan bahwa secara keseluruhan LKS yang dikembangkan valid. Produk awal yang divalidasi oleh 5 validator mendapatkan penilaian yang "tinggi". Hal ini disebabkan oleh ketaatan terhadap pedoman pengembangan LKS yang ada. Menurut Andi Prastowo (2012), LKS yang merupakan bagian dari perangkat pembelajaran yang dikembang kan sesuai dengan pedoman yang ada, akan berpengaruh pada kualitas pembelajaran di kelas.

Hasil respon pengguna dalam hal ini guru dan siswa mengindikasikan bahwa konsep sains berkaitan dengan budaya di masyarakat, diharapkan mampu memuncul keinginan untuk berinteraksi dengan lingkungan secara lebih bijaksana. Menurut Baynes \& Austin (2012) memasukkan budaya yang merupakan unsur dari kearifan lokal dalam kurikulum sekolah, bermanfaat bagi semua siswa. Kearifan lokal dapat membantu siswa dalam menghubungkan ilmu pengetahuan dan mengembangkan identitas budaya yang positif sehingga penbelajaran menjadi lebih bermakna.

Tabel 6. Hasil validasi format isi LKS berbasis kearifan lokal

\begin{tabular}{|c|c|c|}
\hline Indikator & V-I & $\mathrm{V}-2$ \\
\hline $\begin{array}{l}\text { Memberi peluang keggiatan } \\
\text { bagi yang cepat maupun } \\
\text { yang lambat }\end{array}$ & 3,13 & 3,13 \\
\hline $\begin{array}{l}\text { Membuat langkah-langkah } \\
\text { untuk menemukan apa yang } \\
\text { hendak dicapai }\end{array}$ & 3,18 & 3,23 \\
\hline $\begin{array}{l}\text { Memberikan kegiatan } \\
\text { untuk pengembangan } \\
\text { hubungan sosial }\end{array}$ & 3,18 & 3,23 \\
\hline $\begin{array}{l}\text { Kalimat yang digunakan } \\
\text { sederhana dan jelas }\end{array}$ & 3,08 & 3,08 \\
\hline $\begin{array}{l}\text { Pertanyaan disusun secara } \\
\text { sistematis }\end{array}$ & 3,18 & 3,18 \\
\hline $\begin{array}{l}\text { Tersedia ruang yang cukup } \\
\text { untuk menuliskan jawaban } \\
\text { atau untuk menggambar }\end{array}$ & 3,18 & 3,18 \\
\hline $\begin{array}{l}\text { Menvantumkan tujaun } \\
\text { kegiatan }\end{array}$ & 3,15 & 3,15 \\
\hline $\begin{array}{l}\text { Ditulis dengan } \\
\text { menggunakan huruf cetak }\end{array}$ & 3,25 & 3,25 \\
\hline $\begin{array}{l}\text { Huruf untuk topik dengan } \\
\text { informasi atau instruksi } \\
\text { telah jelas bedanya }\end{array}$ & 3,23 & 3,23 \\
\hline Gambar cukup jelas & 3,15 & 3,15 \\
\hline Rata-rata/Kategori & $\begin{array}{l}3,17 / \\
\mathrm{T}\end{array}$ & $\begin{array}{l}3,18 / \\
\mathrm{T}\end{array}$ \\
\hline
\end{tabular}

Tabel 7. Hasil respon pengguna terhadap LKS berbasis kearifan lokal

\begin{tabular}{lll}
\hline Pengguna & Rata-rata & \multicolumn{1}{c}{ Kategori } \\
\hline Guru & 3,29 & Sangat Tinggi \\
Siswa & 3,18 & Tinggi \\
\hline
\end{tabular}

Hasil penelitian ini, mengindikasikan bahwa kearifan lokal haruslah diintegrasikan di dalam pembelajaran sains di sekolah. Hal ini sejalan dengan penelitian Castagno, Brayboy, (2008) yang menyataka bahwa kearifan lokal mampu menguhubungkan sains 
dengan kehidupan sehari-hari sehingga memudahkan bagi guru untuk menjelaskan informasi kepada siswa. Siswa perlu dibekali pendidikan yang sesuai dengan nilai-nilai konservasi dalam hali ini adalah kearifan lokal. Hal ini bertujuan agar potensi intelektual yang dimiliki, diimbangi oleh kecerdasan emosional, sosial, dan spiritual yang sangat dibutuhkan untuk berkompetisi (Marukhi, 2012).

\section{Kesimpulan dan Saran}

LKS yang dikembangkan dinyatakan valid dimana validitas format LKS dengan kategori tinggi. Validitas isi LKS berkategori tinggi. Respon pengguna dalam hal ini guru dan siswa menunjukkan bahwa LKS yang dikembangkan memberikan respon yang sangat tinggi dan tinggi sehingga LKS berbasis kearifan lokal ini dinyatakan valid dan layak digunakan.

Penelitian ini diharapkan dapat dilanjut kan ke tahap ujicoba skala besar (disseminate) dan dikembangkan pada pokok bahasan lain sehingga bisa lebih mengeksplor kearifan lokal yang ada.

\section{Daftar Pustaka}

Andi Prastowo, 2012. Panduan Kreatif Membuat Bahan Ajar Inovatif. Diva Press, Yogjakarta.

Baynes, R., \& Austin, J., 2012. Indigenous Knowledge in the Australian National Curriculum for Science: from Conjec ture to Classroom Practice. Paper Presented at the 5th Biennial Inter national Indigenous Development Research Conference, Auckland: New Zealand.

Belawati, Tian, et al., 2003. Pengembangan BahanAjar. Pusat penerbitan Universi tas Terbuka, Jakarta.
Castagno, A.E., Brayboy, B.M.J., 2008. "Culturally Responsive Schooling for Indigenous Youth: A Review of Literature" dalam Review of Educa tional Research, 78 (4), 941-993.

Clayton, S. \& Myers, G., 2009. Psikologi Konservasi (Terjemahan). Pustaka Pelajar. Jakarta, Indonesia.

Gondwe, N. \& Longnecker, N., 2014. Scientific and Cultural Knowledge in Intercultural Science Education: Stu dent Perceptions of Common Ground. Res Sci Educ. Springer.

Hairida, 2010. Pemanfaatan Budaya dan Teknologi Lokal dalam Rangka Pengembangan Sains. Jurnal Pendidi kan Matematika dan IPA, Vol.1. No.1. Januari 2010.

Masrukhi, 2012. Membangun Karakter Maha siswa Berbasis Nilai Konservasi. Arti kel Simposium Pendidikan dan Kemaha siswaan di Universitas Sebelas Maret. 23 Juni 2012.

Nur, Mohamad, 2011. Model Pengembangan Perangkat Pembelajaran, Unesa. Surabaya.

Rusmiati, A., 2007. Pengembangan Model Pengajaran dengan Problem Based Instruction pada Pokok Bahasan Untuk Menumbuhkan Keterampilan Proses Sains. Universitas Negeri Semarang, Semarang.

Sugiyono, 2010. Metodologi Penelitian Pendidikan. Alfabeta, Bandung.

Trianto, 2013. Model Pembelajaran Terpadu. PT. Bumi Aksara, Jakarta.

Zuhdan K. Prasetyo, 2013. Pembelajaran Sains Berbasis Kearifan Lokal. Makalah seminar nasional fisika dan pendidikan fisika 2013 Program Studi Pendidikan Fisika PMIPA. FKIP Universitas Sebelas Maret. Kemendikbud. 